A N N A L E S

UNIVERSITATIS MARIAE CURIE-SKŁODOWSKA LUBLIN - POLONIA

VOL. XXX, 2

SECTIO J

2017

Wyższa Szkoła Oficerska Sił Powietrznych w Dęblinie.

Wydział Bezpieczeństwa Narodowego i Logistyki

\title{
JANUSZ ŚLUSARSKI
}

jaolski@interia.pl

\section{Sztuka zarządzania zasobami własnymi oraz zespołu jako metakompetencja pilota i pilota-instruktora funkcjonujacego w sytuacjach trudnych i niebezpiecznych}

An Art of One's Own and Team Resources Management as a Meta-Competence of a Pilot and a Flight Instructor Who Function in Difficult and Dangerous Situations

\section{STRESZCZENIE}

Przedstawiona w artykule specyfika pracy współczesnego pilota i pilota-instruktora wojskowego statku powietrznego posłużyła do zwrócenia uwagi na potrzebę zaakcentowania znaczenia dla jego efektywnego działania szkoleniowego kompetencji miękkich (nietechnicznych) oraz metakompetencji.

W oparciu o literaturę przedmiotu autor artykułu formułuje założenia teoretyczne dotyczące rosnącego znaczenia we współczesnych organizacjach kompetencji miękkich i metakompetencji zatrudnionych tu pracowników. Przyczyn tego można się doszukiwać m.in. w rosnącej złożoności zadań, które wykonują oni na swoich stanowiskach pracy, oraz generowania tym samym coraz częściej sytuacji trudnych i niebezpiecznych. Tak zdefiniowane wojskowe organizacje lotnicze wymagają zdaniem autora doskonalenia zatrudnionych osób w zakresie zarządzania zasobami własnymi i zespołu. Osobą, która nie tylko w lotnictwie wojskowym ma szczególny wpływ na jakość przygotowania zawodowego przyszłego personelu lotniczego (pilota wojskowego), jest pilot-instruktor. Dlatego to stanowisko pracy jest głównym przedmiotem badań własnych przeprowadzonych w reprezentatywnej dla środowiska personelu lotniczego grupie pilotów i pilotów-instruktorów wojskowych statków powietrznych.

Efektem rozważań teoretycznych oraz analiz, opisu i interpretacji danych empirycznych są sformułowane wnioski, mające również charakter wskazówek praktycznych, które mogą mieć znaczenie dla procesu systematycznego doskonalenia bezpieczeństwa wykonywania zadań w powie- 
trzu. Każda podpowiedź dotycząca doskonalenia czynnika ludzkiego jest szczególnie ważna dla współczesnego lotnictwa wojskowego, ponieważ to właśnie czynnik ludzki odpowiada dzisiaj za 70-80\% niebezpiecznych zdarzeń w lotnictwie (incydentów, wypadków i katastrof).

Słowa kluczowe: pilot-instruktor; cechy charakteru i osobowości; relacje interpersonalne; kompetencje miękkie; kompetencje nietechniczne; metakompetencje; sytuacje trudne; sytuacje niebezpieczne

\section{WPROWADZENIE}

Obecnie działanie w samolocie/śmigłowcu wojskowym to proces twórczy (współtwórczy), ciągły odbiór bodźców i reakcje na nie, a przede wszystkim przewaga udziału pracy umysłowej. Warunki ekstremalnie trudnego środowiska pracy, jakim jest kabina współczesnego statku powietrznego, obnażają słabości organizmu ludzkiego w zakresie tolerancji czynników lotu. Jednocześnie zmiany stylu latania, które zaszły w ciągu ostatnich lat, powodują, iż dopuszczalny margines błędu jest bardzo mały i każde odejście od optymalnego profilu lotu może mieć tragiczne skutki (Mikuliszyn, Truszczyński 2000).

Dlatego z jednej strony tak istotne jest ćwiczenie nawyków niezbędnych do właściwego reagowania w sytuacjach awaryjnych, służących niejako „oszukaniu" fizjologii własnego organizmu i zapewnieniu możliwości działania w sytuacjach, w których niewytrenowany organizm nie byłby w stanie sobie poradzić. $\mathrm{Z}$ drugiej strony szczególnym wsparciem dla osób pracujących w takich warunkach jest właściwe współdziałanie zespołu, prawidłowe wykorzystanie indywidualnych możliwości każdego z członków załogi lotniczej (optymalne zarządzanie jej zasobami). Prawidłowe współdziałanie w zespole (załodze) jest główną ideą szkolenia $\mathrm{CRM}^{1}$. Celem jest tu przede wszystkim praktyczna nauka współpracy (najczęściej realizowana z wykorzystaniem specjalistycznych symulatorów lotni$\mathrm{czych}^{2}$ ), przygotowująca każdego członka załogi do efektywnego współdziałania w trakcie wykonywania misji i zadań lotniczych. Podstawą współdziałania w zespole (załodze) jest pojedynczy człowiek. Jednoznaczny odbiór informacji przez współpracujących ze sobą ludzi oraz wykonywanie zadań w ramach wzajemnie uzupełniających się ról i stałe wzajemne monitorowanie się dają efekt współdziałania, który zwiększa nie tylko skuteczność działania, ale również jego niezawodność, a tym samym bezpieczeństwo wykonywanych zadań lotniczych (Makarowski, Smolicz 2012).

\footnotetext{
${ }^{1}$ CRM (Crew/Cocpit/Company Resources Management) - Zarządzanie Zasobami Załogi/Kokpitu/Organizacji.

${ }^{2}$ Symulator FNPT II MCC dla danego typu statku powietrznego z modułem przeznaczonym do szkolenia w zakresie współpracy w załodze (por. Jancelewicz 2009, s. 202-216).
} 
Szczególną rolę do spełnienia ma, w kontekście przedstawionych powyżej rozważań na temat szkolenia CRM, pilot-instruktor wojskowego statku powietrznego jako nauczyciel przygotowujący do zawodów trudnych i niebezpiecznych (tzn. zawodu pilota wojskowego). Wszelkie braki w późniejszym funkcjonowaniu pilota wojskowego jako członka zespołu (załogi) czy organizacji lotniczej mają często swoje źródło w błędach szkoleniowych, jakie popełnia pilot-instruktor wojskowego statku powietrznego. Dlatego każdy pilot-instruktor wojskowego statku powietrznego poznaje i rozwija w ramach kursu instruktorskiego, a następnie systematycznie doskonali (pogłębia i utrwala) w trakcie kursów instruktorsko-metodycznych ${ }^{3}$ swoje kompetencje miękkie (określane w terminologii CRM jako nietechniczne - NOTECH; por. Klich 2010, 2011; Makarowski, Smolicz 2012).

\section{KOMPETENCJE MIEKKIE I METAKOMPETENCJE CZŁOWIEKA \\ JAKO ODPOWIEDŹ NA ZŁOŻONOŚĆ ŚRODOWISKA PRACY \\ ORAZ GENEROWANE TU SYTUACJE TRUDNE I NIEBEZPIECZNE}

Kompetencje pracowników są głównym elementem kompetencji organizacji. Przecież to ludzie - ich wiedza i umiejętności, twórcze myślenie, ambicje i zaangażowanie, a także zdolności do współpracy - kształtują i rozwijają przedsiębiorstwo, produkty i technologie, budują markę firmy i jej wyrobów, wpływają na zainteresowanie klientów czy zdolności produkcyjne. Jak dobitnie i zarazem lapidarnie wyraził to K. Obłój (2000), „każda firma jest w ostatecznym rachunku skumulowaną wiedzą byłych i obecnych pracowników". Można by dodać, że także ich doświadczenia i postaw, a zatem po prostu ich kompetencji (za: Oleksyn 2010, s. 24).

Zdaniem wielu autorów istnieją różne - szersze i węższe - definicje kompetencji pracowników. Na rys. 1 przedstawiono model holistyczny kompetencji. Według T. Oleksyna jest on interesujący ze względu na uniwersalność ujęcia oraz wprowadzone dodatkowo pojęcie metakompetencji.

Zgodnie z modelem przedstawionym na rys. 1 kompetencje można podzielić na:

1. Kompetencje poznawcze (kognitywne), które wiążą się ze zdolnością do uczenia się, rozumienia i zapamiętywania, otwartością, ciekawością świata i świeżością spojrzenia. Są one większe, gdy ludzie nie kierują się stereotypami i uprzedzeniami oraz nie są nadmiernie podatni na wpływy innych. Największa ciekawość i pasja poznawcza występuje zazwyczaj we wczesnych okresach życia, w dzieciństwie i młodości, choć zda-

${ }^{3}$ Autor artykułu jest współautorem aktualnie realizowanych w WSOSP w Dęblinie programów kursów instruktorskiego i instruktorsko-metodycznego dla pilotów wojskowych oraz kursu dla instruktorów CRM. 


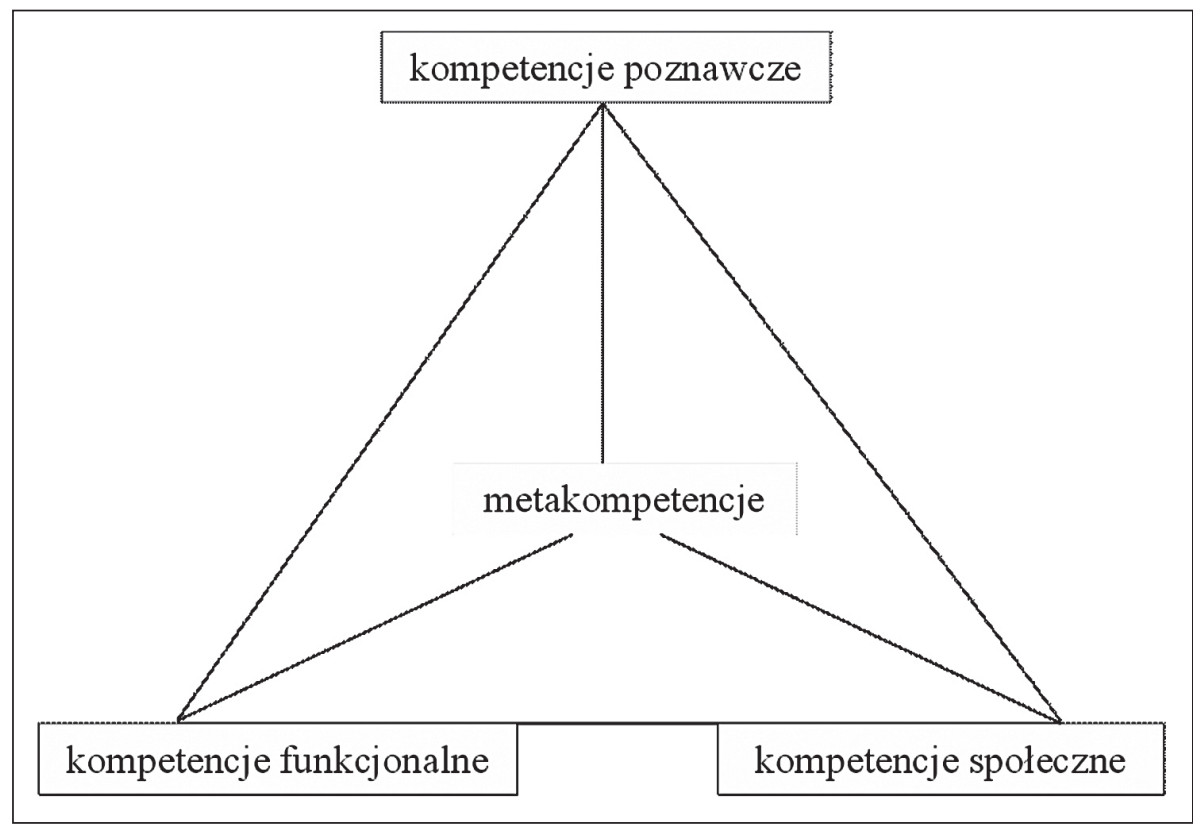

Rys. 1. Holistyczny model kompetencji F. Delamare'a Le Deista i J. Wintertona Źródło: (Delamare Le Deist, Winterton 2005, s. 40, za: Oleksyn 2010, s. 24).

rza się, że towarzyszą człowiekowi przez całe życie (szczególnie ważne są i u szkolącego pilota-instruktora, i u szkolonego ucznia).

2. Kompetencje funkcjonalne, które są związane ze sprawnym funkcjonowaniem człowieka - wykonywaniem danego zawodu czy pracą na określonym stanowisku. W każdym zawodzie i na każdym stanowisku pracy można rozwinąć specyficzną grupę kompetencji, które są niezbędne albo przynajmniej przydatne w samodzielnej i efektywnej pracy (np. technika pilotowania statkiem powietrznym danego typu, szczególnie ważna kompetencja dla każdego pilota-instruktora wojskowego statku powietrznego oraz ostateczny cel realizowanego szkolenia lotniczego).

3. Kompetencje społeczne dotyczą sfery kontaktów z innymi ludźmi. Wyrażają się w łatwości nawiązywania i utrzymywania kontaktów, empatii, zdolności do współpracy, w dążeniu do wspólnych celów, umiejętności przezwyciężania różnic w poglądach i interesach oraz rozwiązywania konfliktów (są to szczególnie ważne kompetencje dla każdego pilota-instruktora wojskowego statku powietrznego).

4. Metakompetencje wiążą się z jednej strony ze zdolnością do uczenia się i refleksji, a z drugiej z umiejętnością radzenia sobie w warunkach niepewności, co zapewne będzie coraz bardziej przydatne (w przypadku pi- 
lota-instruktora wojskowego statku powietrznego jest to szczególnie istotna kompetencja, związana z niezbędnym poziomem refleksji gwarantującym efektywne zarządzanie błędami własnymi i szkolonych uczniów oraz systematycznym uczeniem się na nich).

Tego typu typologia kompetencji, według F. Delamare'a Le Deista i J. Wintertona (2005), jest najbardziej przydatna do kształtowania rozwoju zawodowego. Optymalny rozwój jednostki polega na aktywnej reorganizacji i integracji przez nią rozmaitych kompetencji nabytych w ciągu życia. Przy czym większość kompetencji zawiera w sobie potencjalną zdolność do generowania nowych zachowań, do różnorodnego kombinowania i przekształcania przyswojonych elementów (Korporowicz 1998). W kontekście tych rozważań można przyjąć, że kompetencje zawodowe to struktura poznawcza złożona z określonych zdolności, zasilana wiedzą i doświadczeniami, zbudowana na zespole przekonań, iż za pomocą tych zdolności warto i można w danym kontekście sytuacji zachodzących w środowisku pracy inicjować i realizować skutecznie zadania zawodowe zgodnie z przyjętymi standardami (Butkiewicz 1995).

W artykule interesują nas przede wszystkim kompetencje osobiste i społeczne (miękkie, nietechniczne) nauczyciela przygotowującego do zawodów trudnych i niebezpiecznych - pilota i pilota-instruktora wojskowych statków powietrznych. Warto przypomnieć w tym miejscu, że w literaturze występuje zarówno pojęcie kompetencje miękkie, jak i kompetencje twarde (Smółka 2007, 2008; Makarowski, Smolicz 2012).

Otóż kompetencje twarde, według P. Smółki (2007, 2008), wiążą się z posiadaniem specjalistycznej wiedzy i umiejętności, które są nieodzowne dla możliwości pełnienia określonej roli zawodowej lub pracy na danym stanowisku - chodzi tutaj przede wszystkim o wiedzę i umiejętności techniczne. W przypadku pilota-instruktora wojskowego statku powietrznego dotyczą one przede wszystkim techniki pilotowania oraz eksploatacji danego typu samolotu/śmigłowca. Są one przy tym specyficzne dla danego stanowiska pracy i są konieczne, aby móc efektywnie funkcjonować na tym stanowisku (por. Terelak 1988, 20114).

Kompetencje miękkie również wiążą się z posiadaniem wiedzy, umiejętności i postaw, które są podstawą skuteczności działania. Jednak w przeciwieństwie do kompetencji twardych są one nieodzowne dla skuteczności tego działania w wielu różnych kontekstach, rolach zawodowych i na różnych stanowiskach pracy. Umożliwiają one w związku z tym elastyczność kompetencyjną i zdolność odnalezienia się podczas pełnienia rozmaitych obowiązków oraz realizowania różnych zadań. Kompetencje miękkie stanowią generalny potencjał gotowy do wykorzystania w szerokim spektrum sytuacji.

${ }^{4}$ Autor ten twierdzi, że dzisiaj należy mówić już nie tylko o pilocie wojskowego statku powietrznego czy pilocie samolotu odrzutowego, ale wręcz o pilocie konkretnego typu statku powietrznego (np. F-16, Mig-29 itd.). 
Współcześnie coraz bardziej liczą się na wielu stanowiskach elastyczność kompetencyjna i zdolności przystosowawcze (dotyczy to także współczesnego pilota-instruktora wojskowego statku powietrznego, co potwierdzają wyniki badań własnych; por. Ślusarski 2013a, 2014). To właśnie kompetencje miękkie stanowią znaczną część wymaganego na danym stanowisku pracy potencjału, w którego skład wchodzą kompetencje osobiste gwarantujące sprawne zarządzanie sobą (zasobami własnymi, tzn. cechami charakteru i osobowości) oraz kompetencje interpersonalne umożliwiające skuteczną realizację własnych zamierzeń i zleconych zadań w interakcjach społecznych (np. z uczniem - przyszłym pilotem wojskowym), podczas kontaktów z innymi osobami (np. z pozostałymi członkami załogi lotniczej). Do tych ostatnich kompetencji można też zaliczyć sprawne zarządzanie zasobami innych ${ }^{5}$ (tzn. ucznia-pilota wojskowego czy pozostałych członków załogi lotniczej) (por. Klich 2010, 2011; Makarowski, Smolicz 2012).

Badania empiryczne wskazują, że aż 70\% kompetencji determinujących osiąganie ponadprzeciętnych efektów w pracy ma charakter kompetencji miękkich (Cherniss 2000). Dlatego, jeżeli zależy organizacji i/lub konkretnemu pracownikowi na osiąganiu wybitnych rezultatów, należy postawić na kształtowanie, rozwijanie i systematyczne doskonalenie kompetencji miękkich (por. Truszczyński, Biernacki 2010; Zarządzanie zasobami...).

Kompetencje miękkie to termin zbiorczy na określenie kompetencji osobistych oraz kompetencji społecznych. Z funkcjonalnego punktu widzenia zapewniają one sprawne zarządzanie sobą (tzn. zasobem własnych cech charakteru i osobowości) oraz wysoką skuteczność interpersonalną (tzn. zarządzanie zasobami zespołu, załogi). Miękkie umiejętności tworzą podstawowy zasób potencjału każdego z nas, a w przypadku stanowiska pracy pilota-instruktora wojskowego statku powietrznego jako nauczyciela przygotowującego do zawodów trudnych i niebezpiecznych mają szczególne znaczenie. Z kolei deficyty w zakresie umiejętności zarządzania sobą oraz umiejętności społecznych (zarządzania relacjami z innymi) często znacznie ograniczają, a czasem wręcz uniemożliwiają skuteczne wywiązywanie się z obowiązków zawodowych (np. menedżera, lidera, nauczyciela, a także pilota i pilota-instruktora) oraz realizowanie własnych zamierzeń.

Dodajmy w tym miejscu, że szczególną zaletą dobrego menedżera, lidera, nauczyciela (w tym pilota i pilota-instruktora wojskowego statku powietrznego) jest efektywne (a tym samym aktywne i elastyczne) gospodarowanie (zarządzanie) posiadanymi kompetencjami miękkimi w zależności od sytuacji i okoliczności działania (np. szkoleniowe sytuacje normalne a sytuacje trudne, uczeń-przyszły pilot na początkowym etapie szkolenia a uczeń-pilot na końcowym etapie szkolenia). Chodzi tu o to, by umieć wykorzystać wtedy, kiedy jest to niezbędne, walory określonej kompetencji miękkiej (np. właściwej w danej sytuacji cechy

\footnotetext{
${ }^{5}$ Jest to jeden z podstawowych celów szkolenia CRM.
} 
charakteru czy osobowości) lub odsunąć na dalszy plan zastosowanie tej z cech, której wykorzystanie mogłoby okazać się w konkretnej sytuacji nieskuteczne. Tę zdolność elastycznego korzystania ze swoich kompetencji miękkich (którą można nazwać metakompetencją; por. Adamiec, Kożusznik 2001; Oleksyn 2010) cenią coraz częściej i systematycznie rozwijają bardzo dobrzy współcześni menadżerowie, liderzy i nauczyciele (w tym piloci i piloci-instruktorzy wojskowych statków powietrznych ${ }^{6}$; por. Ślusarski 2014). Są to osoby, które znają praktyczny sens powiedzenia: „Młotek jest pożytecznym narzędziem, ale trudno nim obcinać paznokcie" (za: Adamiec, Kożusznik 2001, s. 164). Wiadomo, że taka cecha, jak bycie asertywnym, to ważna kompetencja miękka pilota i pilota-instruktora wojskowego statku powietrznego, ale nie jest ona przydatna w sytuacji trudnej, kiedy uczeń-przyszły pilot wojskowy czy członek załogi nagle popełnia błąd, na który należy zareagować jednoznacznie i wręcz agresywnie, aby skutecznie rozwiązać powstały $\mathrm{w}$ trakcie treningu lotniczego $\mathrm{w}$ powietrzu problem. Zupełnie inaczej wygląda sytuacja, kiedy pilot czy pilot-instruktor ocenia i analizuje popełniony przez ucznia czy innego członka załogi błąd po wykonanym locie, w trakcie jego omawiania (debriefing). Szczególną zaletą dobrze poprowadzonego debriefingu jest stwarzanie przez pilota i pilota-instruktora jak najczęściej odpowiedniej przestrzeni do rozmowy (opartej na pełnym wykorzystywaniu sprzężenia zwrotnego), a tym samym możliwości wypowiedzenia się swojemu uczniowi-przyszłemu pilotowi czy innemu członkowi załogi (por. Makarowski, Smolicz 2012; Truszczyński, Biernacki 20107).

Przedstawione powyżej rozważania potwierdzają również wyniki badań własnych przeprowadzonych $\mathrm{w}$ grupie reprezentatywnej dla środowiska personelu lotniczego, tzn. pilotów i pilotów-instruktorów wojskowych statków powietrznych. Wybrane wyniki tych badań oraz ich analizy, opisy i interpretacja zostaną zaprezentowane w części empirycznej artykułu.

\section{OPIS I INTERPRETACJA WYNIKÓW BADAŃ WŁASNYCH}

Do badania interesujących autora artykułu stanowisk pracy pilota wojskowego oraz pilota-instruktora wojskowego statku powietrznego jako nauczyciela przygotowującego kandydatów do zawodów trudnych i niebezpiecznych (pilotów wojskowych) wykorzystano - opracowany przez zespół pracowników naukowych z Zakładu Psychologii Przemysłowej KUL pod kierownictwem naukowym prof. dr. hab. A. Bieli - Kwestionariusz Lubelski Analizy Stanowiska

\footnotetext{
${ }^{6}$ To szczególnie istotny cel realizowanego w lotnictwie szkolenia CRM.

${ }^{7}$ Precyzyjne zasady przeprowadzenia dobrego debrifingu określa m.in. Instrukcja szkoleń personelu latającego z zakresu zarzadzania zasobami załogi CRM w lotnictwie Sit Zbrojnych RP (2013) oraz Poradnik - listy kontrolne w zakresie CRM dla personelu latajacego w lotnictwie Sit Zbrojnych $R P$ (2013).
} 
Pracy (KLASP). Metoda ta przeszła etap badań walidacyjnych i może być bezpośrednio wykorzystywana przez psychologów zarówno w praktyce diagnostyczno-selekcyjnej, jak i do badania stanowisk pracy pilota i pilota-instruktora wojskowego statku powietrznego (Biela [red.] 1992; Ślusarski 2013a, 2014).

Wersja KLASP-u z 1992 r. składa się z sześciu części. Część wstępna zawiera pytania na temat zakładu pracy, danych statystycznych oraz normatywnych o stanowisku pracy. Pięć części analiz merytorycznych stanowiska pracy obejmuje łącznie 351 pozycji analitycznych, dotyczących wieloaspektowej charakterystyki danego stanowiska (Biela [red.] 1992; Ślusarski 2013a, 2014).

Dla potrzeb przedstawionych $\mathrm{w}$ artykule badań wykorzystano zaadaptowaną wersję KLASP-u (por. Ślusarski 2013a) ${ }^{8}$. W tym celu wprowadzono niezbędne odniesienia, przykłady i uszczegółowienia w ramach części wstępnej tego kwestionariusza oraz jego pięciu części analiz merytorycznych. Pozwoliły one zaakcentować specyfikę pracy na badanych stanowiskach pracy pilota i pilota-instruktora wojskowego statku powietrznego. Dokonując adaptacji KLASP-u, zachowano oczywiście zasadniczy charakter tego narzędzia badawczego, a szczególnie wierność założeniom, na których oparto jego konstrukcję (Biela [red.] 1992; Biela 2001).

Należy w tym miejscu podkreślić, że w niniejszym opracowaniu została zaprezentowana jedynie ta część otrzymanych danych, która odnosi się do podjętych tu zagadnien, tzn. relacji interpersonalnych oraz cech charakteru i osobowości pilotów i pilotów-instruktorów funkcjonujących w sytuacjach trudnych i niebezpiecznych. Znalazły się tu te dane z KLASP-u, które odnoszą się kolejno do:

A. Relacji interpersonalnych [poniżej zachowano numerację itemów zgodnie z tą, która została przyjęta w KLASP-ie - J.Ś.]:

Praca pilota i pilota-instruktora SP wykonywana jest:

133. Jednoosobowo.

134. Zespołowo.

\section{Praca wymaga:}

135. Współpracy (współdziałania) z innymi osobami.

136. Kierowania innymi pracownikami.

137. Ścisłego kontrolowania pracowników.

138. Świadczenia usług ludziom (np. ratowniczych).

139. Kontaktów z człowiekiem chorym, niepełnosprawnym, rannym, poszkodowanym.

140. Subordynacji, wypełniania poleceń.

141. Tolerancji wobec ludzi.

142. Rywalizacji.

143. Wzajemnego zaufania pracowników.

144. Ograniczenia kontaktów rodzinnych i towarzyskich (priorytet obowiązków służbowych, dyspozycyjność).

${ }^{8}$ Pierwszej adaptacji KLASP-u dokonał autor niniejszej monografii na użytek badań pilotów i pilotów-instruktorów śmigłowców wojskowych. 
145. Ograniczenia kontaktów społecznych (izolacji społecznej).

146. Radzenia sobie w sytuacjach konfliktowych.

B. Cech charakteru [poniżej zachowano numerację itemów zgodnie z tą, która została przyjęta w KLASP-ie - J.Ś.]:

Wynik pracy pilota i pilota-instruktora SP zależy od:

332. Wytrwałości, konsekwencji.

333. Zdecydowania, niewahania się w podejmowaniu decyzji.

334. Poczucia odpowiedzialności (można na nim polegać).

335. Sumienności, uczciwości.

336. Zdyscyplinowania, przestrzegania przepisów, procedur, instrukcji, regulaminów, poleceń, rozkazów.

337. Stałości zasad (kierowania się niezmiennymi zasadami ocen, interpretacji).

338. Zamiłowania do porządku (np. schludny w wyglądzie, ład i porządek w zajmowanym pomieszczeniu służbowym).

339. Empatii (tzn. właściwego rozpoznawania samopoczucia innych, atmosfery w grupie).

C. Innych niektórych cech osobowości [poniżej zachowano numerację itemów zgodnie z tą, która została przyjęta w KLASP-ie - J.Ś.]:

Znaczenie w pracy pilota i pilota-instruktora SP ma:

348. Gotowość do działania w trudnych i niebezpiecznych warunkach.

349. Znajdowanie wyjścia $\mathrm{z}$ trudnych i niebezpiecznych sytuacji.

350. Niezawodność (skuteczność i opanowanie) w sytuacji awaryjnej.

351. Szybkość podejmowania decyzji.

352. Trafność podejmowania decyzji.

Badania zostały przeprowadzone w wojskowych organizacjach lotniczych (jednostkach, bazach, skrzydłach itp.) na terenie kraju oraz w Wyższej Szkole Oficerskiej Sił Powietrznych w Dęblinie w trakcie przebywania badanych osób na kursach specjalistycznych w ramach doskonalenia zawodowego. Badaniami objęto 230-osobową grupę pilotów i pilotów-instruktorów wojskowych statków powietrznych (Ślusarski 2014).

Założono, że dobry pilot-instruktor wojskowego statku powietrznego musi być na początek dobrym pilotem (stąd oceny itemów KLASP-u odnoszące się do stanowiska pracy pilota wojskowego potraktowano jako swoisty fundament wymagań zawodowych, niezbędny dobremu pilotowi-instruktorowi na jego stanowisku), aby następnie dzięki dodatkowym predyspozycjom, cechom i kompetencjom mógł realizować zadania szkoleniowe jako dobry pilot-instruktor samolotu/ śmigłowca wojskowego.

W niniejszym artykule zwrócono uwagę przede wszystkim na te oceny respondentów, które odnoszą się do znaczenia pozycji KLASP-u dla efektywnego funkcjonowania pilota wojskowego oraz pilota-instruktora wojskowego statku powietrznego przygotowującego kandydatów do zawodów trudnych i niebezpiecznych (pilota wojskowego), a które są szczególnie ważne jako zasób ich kompetencji miękkich (nietechnicznych) i metakompetencji na tych stanowiskach. 
Stąd scharakteryzowano poniżej oceniane przez badanych pilotów i pilotów-instruktorów wojskowych statków powietrznych grupy itemów KLASP-u odnoszące się przede wszystkim do takich kolejno czynników, jak relacje interpersonalne oraz cechy charakteru i osobowości kandydatów na te stanowiska pracy.

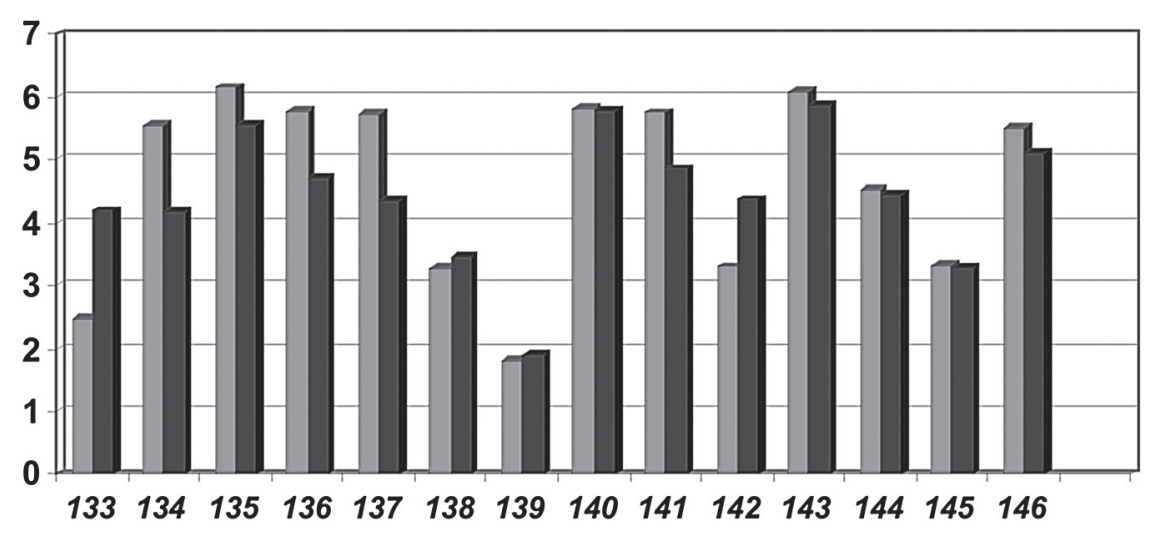

$\square$ Instruktor $\quad \square$ Pilot

Uwaga: wartości liczbowe na osi pionowej odpowiadają 7-stopniowej skali, która została zastosowana w KLASP-ie; wartości liczbowe na osi poziomej odpowiadają kolejnym numerom pozycji KLASP-u; oprócz pozycji KLASP-u: P139, P140, P144 i P145, wszystkie pozostałe pozycje wymienione na rysunku zostały zróżnicowane w sposób istotny statystycznie $\left({ }^{*} \mathrm{p}<0,05 ;{ }^{*} \mathrm{p}<0,01\right.$; $* * * \mathrm{p}<0,001)$ przez respondentów $\mathrm{w}$ odniesieniu do ocenianych przez nich stanowisk pracy pilota i pilota-instruktora.

Rys. 2. Rozkład graficzny wartości średnich arytmetycznych, charakteryzujących oceny badanych pilotów i pilotów-instruktorów, dotyczących znaczenia pozycji wymienionych w KLASP-ie

Źródło: opracowanie własne.

Na podstawie przedstawionych na rys. 1 danych można stwierdzić, że badani piloci i piloci-instruktorzy ocenili zdecydowaną większość pozycji KLASP-u, które odnoszą się do relacji interpersonalnych na tych stanowiskach, jako mające bardzo duże lub znaczne zastosowanie (6 lub 5 na 7-stopniowej skali zastosowanej w KLASP-ie). Jeżeli chodzi o stanowiska pilota i pilota-instruktora, to respondenci najwyższe wagi (6 i 5) przypisali takim cechom pracy na tych stanowiskach, jak praca pilota i pilota-instruktora wymagające przede wszystkim: wzajemnego zaufania (P143); subordynacji (P140); współpracy (współdziałania) $\mathrm{z}$ innymi osobami (P135); radzenia sobie w sytuacjach konfliktowych (P146). 
Przy tym wagi powyżej 5 badani piloci i piloci-instruktorzy przypisali również takim cechom pracy na stanowisku pilota-instruktora, jak: kierowanie innymi pracownikami (P136); ścisłe kontrolowanie pracowników (P137); tolerancja wobec ludzi (P141).

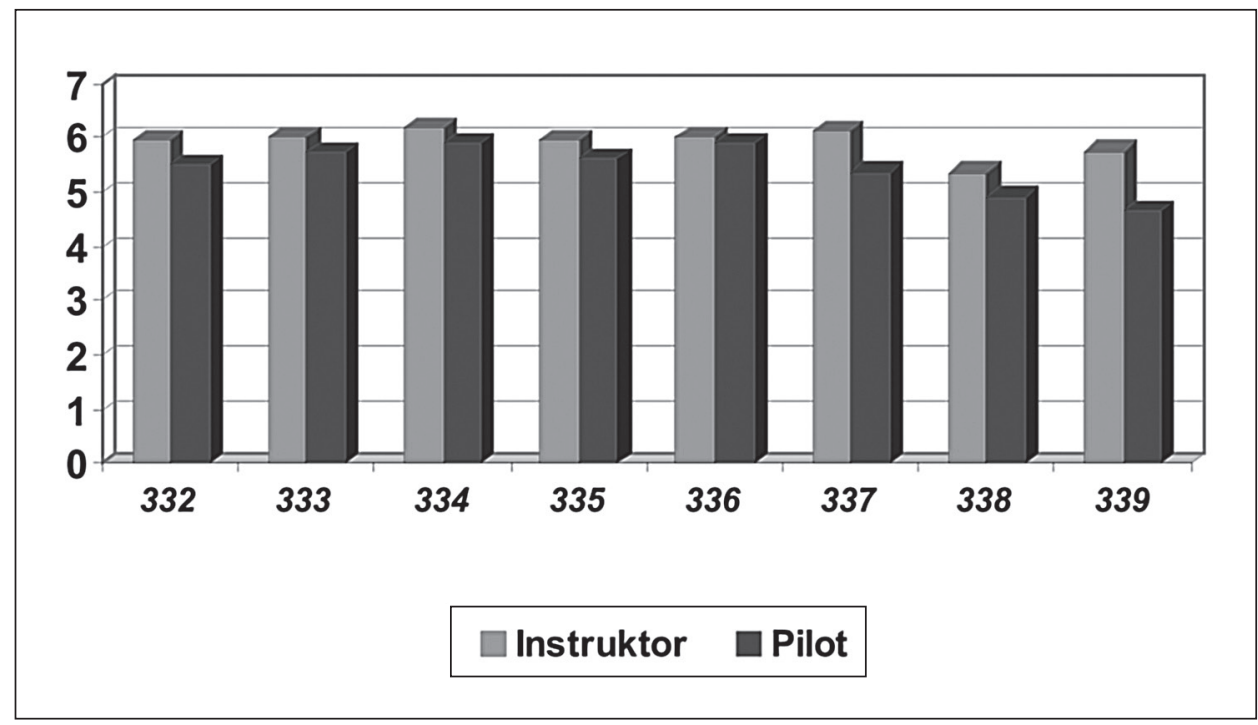

Uwaga: wartości liczbowe na osi pionowej odpowiadają 7-stopniowej skali, która została zastosowana w KLASP-ie; wartości liczbowe na osi poziomej odpowiadają kolejnym numerom pozycji KLASP-u; wszystkie pozycje wymienione na rysunku zostały zróżnicowane w sposób istotny statystycznie $(* \mathrm{p}<0,05 ; * * \mathrm{p}<0,01 ; * * * \mathrm{p}<0,001)$ przez respondentów w odniesieniu do ocenianych przez nich stanowisk pracy pilota i pilota-instruktora.

Rys. 3. Rozkład graficzny wartości średnich arytmetycznych, charakteryzujących oceny badanych pilotów i pilotów-instruktorów, dotyczących znaczenia pozycji wymienionych w KLASP-ie

Źródło: opracowanie własne.

Badani piloci i piloci-instruktorzy, oceniając znaczenie cech charakteru u osób zatrudnionych na analizowanych stanowiskach pracy, najwyższe wagi (6 i powyżej na 7-stopniowej skali zastosowanej w KLASP-ie) przypisali tym cechom jedynie w przypadku osób zatrudnionych na stanowisku pilota-instruktora. Są to kolejno następujące $\mathrm{z}$ nich: poczucie odpowiedzialności (można na nim polegać; P334); stałość zasad (kierowanie się niezmiennymi zasadami ocen, interpretacji; P337); zdecydowanie, niewahanie się w podejmowaniu decyzji (P333); zdyscyplinowanie, przestrzeganie przepisów, instrukcji, poleceń (P336). Także w przypadku takich cech charakteru, jak empatia (tzn. właściwe rozpoznawanie samopoczucia innych, atmosfery w grupie; P339) oraz zamiłowanie do porządku 
(np. schludny wygląd; P338), badani orzekli, że są w wysokim stopniu wymagane przede wszystkim na stanowisku pilota-instruktora (wagi powyżej 5 na 7-stopniowej skali zastosowanej w KLASP-ie; por. rys. 3).

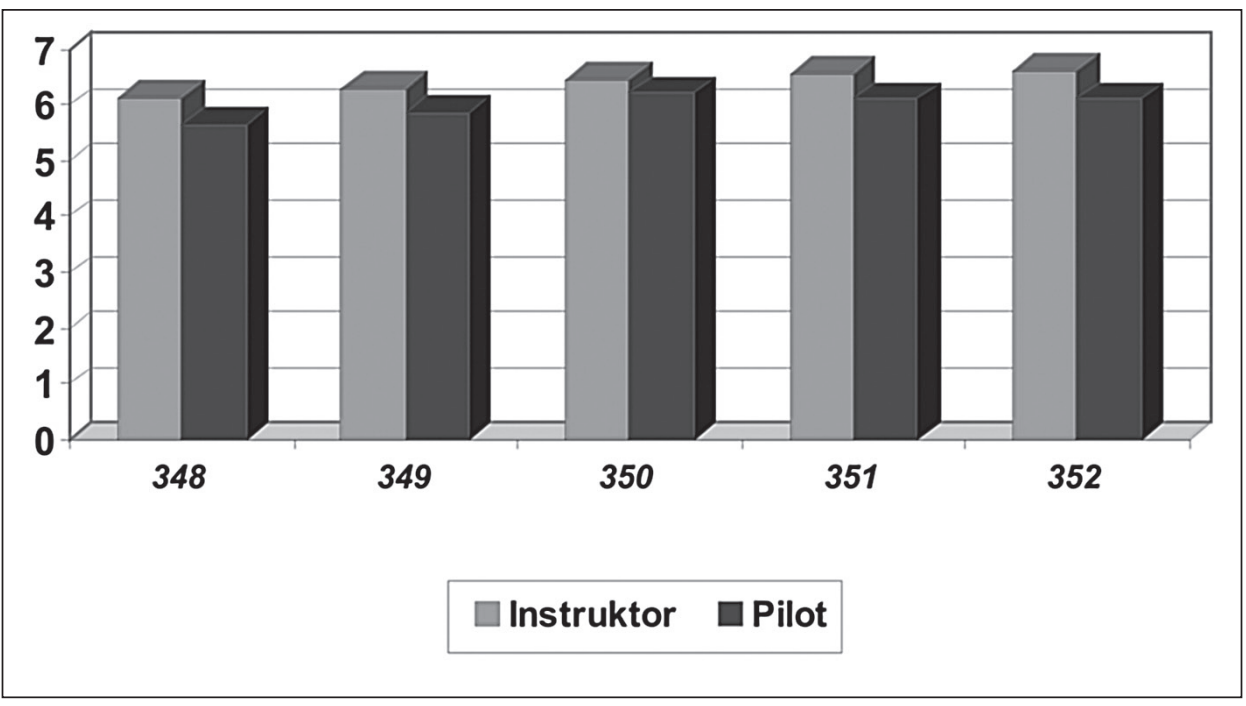

Uwaga: wartości liczbowe na osi pionowej odpowiadają 7-stopniowej skali, która została zastosowana w KLASP-ie; wartości liczbowe na osi poziomej odpowiadają kolejnym numerom pozycji KLASP-u; wszystkie pozycje wymienione na rysunku zostały zróżnicowane w sposób istotny statystycznie $\left({ }^{*} \mathrm{p}<0,05 ; * * \mathrm{p}<0,01 ; * * * \mathrm{p}<0,001\right)$ przez respondentów $\mathrm{w}$ odniesieniu do ocenianych przez nich stanowisk pracy pilota i pilota-instruktora.

Rys. 4. Rozkład graficzny wartości średnich arytmetycznych, charakteryzujących oceny badanych pilotów i pilotów-instruktorów, dotyczących znaczenia pozycji wymienionych w KLASP-ie

Źródło: opracowanie własne.

Badani piloci i piloci-instruktorzy, oceniając znaczenie innych niektórych cech osobowości u osób zatrudnionych na analizowanych stanowiskach pracy, najwyższe wagi (6 i powyżej na 7-stopniowej skali zastosowanej w KLASP-ie) przypisali takim spośród nich, jak: niezawodność w sytuacji awaryjnej (P350); szybkość (P351); trafność w podejmowaniu decyzji (P352). Oprócz tego wagi powyżej 6 na 7-stopniowej skali zastosowanej w KLASP-ie respondenci przypisali takim innym niektórym cechom osobowości, jak gotowość do działania w trudnych i niebezpiecznych warunkach (P348) oraz znajdowanie wyjścia z trudnych i niebezpiecznych sytuacji (P349), ale tylko osobom zatrudnionym na stanowisku pracy pilota-instruktora (por. rys. 4). 
Przedstawione analizy wyników badań własnych potwierdziły w dużym stopniu specyfikę pracy pilotów i pilotów-instruktorów wojskowych statków powietrznych. Są one przy tym ważną odpowiedzią osób wykonujących zadania w tak złożonym środowisku pracy, które często generuje sytuacje trudne i niebezpieczne. Środowisko pracy współczesnego pilota i pilota-instruktora wojskowego statku powietrznego jest obecnie szczególnym wyzwaniem dla funkcjonującego w nim człowieka. Z jednej strony nowoczesne rozwiązania technologiczne i ergonomiczne czynią wojskowy statek powietrzny bardziej przyjaznym człowiekowi i nobilitują jego działania, które coraz mocniej absorbują umysły zatrudnionych tu osób (67\% zadań wykonywanych przez pilota nowoczesnego statku powietrznego wiąże się z wysiłkiem umysłowym, zob. Mikuliszyn, Truszczyński 2000; jest on definiowany jako operator informacyjno-decyzyjny, zob. Biela 1993, 1994; Morawski 1994; Terelak 1988, 2011). Z drugiej strony nowoczesne rozwiązania stawiają temu samemu człowiekowi szczególnie złożone i zarazem trudne oraz niebezpieczne wyzwania.

Odpowiedzią na nowe warunki pracy w lotnictwie wojskowym jest systematycznie doskonalony system doboru kandydatów na najważniejsze stanowiska pracy, tzn. pilota i pilota-instruktora wojskowego statku powietrznego. Jedną z dróg konstruowania systemu doboru na te stanowiska, który spełnia w dużym stopniu oczekiwania współczesnych organizacji lotniczych, jest badanie opinii doświadczonych osób zatrudnionych na tego typu stanowiskach. Takie reprezentatywne dla środowiska personelu lotniczego grono doświadczonych osób (niczym ekspertów, sędziów kompetentnych) jest szczególnie istotnym źródłem trafnych, wiarygodnych i rzetelnych informacji w tym zakresie. Wydaje się, że bardzo pomocnym narzędziem badawczym, które pozwala zebrać wielowymiarowe i wieloaspektowe informacje od takiego grona osób (tzn. doświadczonych pilotów i pilotów-instruktorów wojskowych statków powietrznych), jest scharakteryzowany powyżej i wykorzystany w badaniach własnych KLASP (por. Biela [red.] 1992; Ślusarski 2013a, 2014).

Przedstawione w opracowaniu wyniki badań własnych stanowią jedynie wycinek całości danych zebranych $\mathrm{w}$ trakcie analiz stanowisk pracy pilotów i pilotów-instruktorów wojskowych statków powietrznych. Zaprezentowane wyniki są egzemplifikacją tych opinii i ocen respondentów, które odnoszą się wprost do znaczenia na charakteryzowanych stanowiskach pracy kompetencji miękkich, nietechnicznych (tzn. związanych z opanowaniem pewnej niezbędnej każdemu pilotowi i pilotowi-instruktorowi sztuki zarządzania zasobami własnymi i zespołu) oraz metakompetencji. Na podstawie przedstawionej analizy danych oraz ich opisu i interpretacji można sformułować kilka istotnych wniosków, mających - przede wszystkim dla środowiska lotniczego - charakter wskazówek praktycznych. 
Po pierwsze, badani piloci i piloci-instruktorzy wojskowych statków powietrznych wyraźnie akcentują znaczenie na ocenianych stanowiskach pracy kompetencji miękkich (nietechnicznych) i metakompetencji, przypisując zdecydowanej większości z nich najwyższe wagi (6 i powyżej na 7-stopniowej skali zastosowanej w KLASP-ie).

Po drugie, zdecydowana większość ocenianych kompetencji miękkich (nietechnicznych) i metakompetencji została zróżnicowana w sposób istotny statystycznie (na poziomie istotności $* \mathrm{p}<0,05 ; * * \mathrm{p}<0,01 ; * * * \mathrm{p}<0,001$ ) przez respondentów w odniesieniu do stanowisk pracy pilota i pilota-instruktora. Przy czym we wszystkich przypadkach tego zróżnicowania wyższą rangę na 7-stopniowej skali badani przypisywali stanowisku pracy pilota-instruktora wojskowego statku powietrznego.

Po trzecie, można przyjąć na podstawie otrzymanych wyników badań własnych, że stanowisko pilota-instruktora jako nauczyciela przygotowującego kandydatów do zawodów trudnych i niebezpiecznych jest stanowiskiem generującym częściej tzw. sytuacje silne (tzn. nowe, zaskakujące, złożone, trudne i niebezpieczne) niż stanowisko pilota wojskowego (Mischel 1968; Ślusarski 2013b, 2011).

Po czwarte, w kontekście przestawionych wyników badań szczególnego znaczenia nabiera dalsza potrzeba kształcenia, szkolenia i doskonalenia personelu lotniczego w zakresie zarządzania zasobami własnymi i innych (zespołu, załogi) oraz współpracy w zespole, załodze i organizacji (Crew/Cockpit/Company Resource Management - CRM). Warto dodać, że celem zasadniczym tych szkoleń jest szczególnie ważne dla każdego lotnictwa bezpieczeństwo wykonywania zadań w powietrzu, które bardzo często jest zagrożone z powodu ograniczeń i zawodności czynnika ludzkiego ${ }^{9}$ (por. Dąbrowska 2011; Klich 2011; Makarowski, Smolicz 2011; Morawski 2005).

Po piąte, o kompetencjach przyszłego pilota decyduje w dużym stopniu jakość szkolenia (treningu) lotniczego, za którego organizację i realizację odpowiada przede wszystkim pilot-instruktor jako nauczyciel przygotowujący kandydatów do zawodów trudnych i niebezpiecznych (pilotów wojskowych). Dobór na to stanowisko pracy, kształcenie i szkolenie przyszłego pilota-instruktora oraz dalsze jego doskonalenie w ramach kursów instruktorsko-metodycznych ${ }^{10}$ wymagają stałej i szczególnej uwagi w organizacjach lotniczych.

\footnotetext{
${ }^{9}$ Czynnik ludzki to czynnik spowodowany przez konkretne jednostki i grupy ludzkie wypełniające struktury organizacyjne oraz realizujące w organizacjach zarówno obowiązki i zadania wynikające z pełnionych przez siebie ról, jak i swoje własne, prywatne cele i dążenia. Najczęściej są używane określenia, które służą podkreśleniu znaczenia ludzi dla realizacji celów organizacyjnych i uznania ich za podstawowy składnik ekonomicznej wartości organizacji. W tym znaczeniu mówimy o „zasobach ludzkich” (por. Dąbrowska 2011).

${ }^{10}$ Autor artykułu jest współautorem programów aktualnie realizowanych w Wyższej Szkole Oficerskiej Sił Powietrznych w Dęblinie: kursów instruktorskich dla przyszłych pilotów-instruktorów oraz kursów instruktorsko-metodycznych dla osób pełniących już tę rolę.
} 


\section{BIBLIOGRAFIA}

Adamiec M., Kożusznik B. (2001), Sztuka zarządzania soba, Warszawa: PWN.

Biela A. (1993), Błędy człowieka w sytuacjach podejmowania decyzji ryzykownych, „Ergonomia”, nr 16(2).

Biela A. (1994), Błędy człowieka w sytuacjach podejmowania decyzji ryzykownych, Dęblin: WSOSP. Biuletyn 2 (65) 94.

Biela A. (2001), Wymiary decyzji menedżerskich, Lublin: Towarzystwo Naukowe Katolickiego Uniwersytetu Lubelskiego.

Biela A. (red.) (1992), Kwestionariusz Lubelski Analizy Stanowiska Pracy. Założenia teoretyczne, metodologia konstrukcji oraz metodyka badań kwestionariuszem, Lublin: Redakcja Wydawnictw KUL.

Butkiewicz M. (1995), Model Polskich Standardów Kwalifikacji Zawodowych, Warszawa-Radom: Wydawnictwo Instytutu Technologii Eksploatacji.

Cherniss C. (2000), Social and emotional competence in the workplace, [w:] R. Bar-On, J.D.A. Parker (eds.), Handbook of Emotional Intelligence, San Francisco: Jossey-Bass Inc. Publisher.

Dąbrowska J. (2011), Czynnik ludzki w lotnictwie, „Prace Instytutu Lotnictwa”, nr 221.

Delamare Le Deist F., Winterton J. (2005), What is competence?, "Human Resource Development International", Vol. 8, No. 1, DOI: https://doi.org/10.1080/1367886042000338227.

Instrukcja szkoleń personelu latajacego z zakresu zarządzania zasobami załogi CRM w lotnictwie Sit Zbrojnych RP (2013).

Jancelewicz B. (red.), Bezpieczeństwo i niezawodność w lotnictwie, Toruń: Wydawnictwo Adam Marszałek.

Klich E. (2010), Bezpieczeństwo lotów w transporcie lotniczym, Radom: Instytut Technologii i Eksploatacji-PIB.

Klich E. (2011), Bezpieczeństwo lotów, Radom: Instytut Technologii i Eksploatacji - PIB.

Korporowicz L. (1998), Ewaluacja w reformie systemu edukacji, „Polityka Społeczna”, nr 9.

Makarowski R., Smolicz T. (2012), Czynnik ludzki w operacjach lotniczych. Człowiek, możliwości i ograniczenia - uwarunkowania psychofizjologiczne, Kosowizna: Adriana Aviation Sp. z o.o.

Mikuliszyn R., Truszczyński O. (2000), Czynnik ludzki w aspekcie lotów na samolotach super manewrowych, „Polski Przegląd Medycyny Lotniczej”, nr 4.

Mischel W. (1968), Personality and Assessment, New York: Wiley.

Morawski J. (1994), Gospodarka informacja w uktadzie pilot - samolot, Rzeszów-Warszawa: Redakcja Wydawnictw Uczelnianych Politechniki Rzeszowskiej.

Morawski J. (2005), Człowiek i technologia, Tajniki wzajemnych uwarunkowań, Pułtusk: Wyższa Szkoła Humanistyczna im. A. Gieysztora.

Obłój K. (2000), Strategia sukcesu firmy, Warszawa: PWE.

Oleksyn T. (2010), Zarządzanie kompetencjami. Teoria i praktyka, wyd. 2, Kraków: Oficyna a Wolters Kluwer business.

Poradnik - listy kontrolne w zakresie CRM dla personelu latajacego w lotnictwie Sił Zbrojnych RP (2013).

Smółka P. (2007), Generator charyzmy. Kreowanie osobowości menedżera, Gliwice: Wydawnictwo Helion.

Smółka P. (2008), Kompetencje społeczne. Metody pomiaru i doskonalenia umiejętności interpersonalnych, Kraków: Wolters Kluwer.

Ślusarski J. (2011), Nauczyciel zawodu, w którym dominują sytuacje trudne i ekstremalne, [w:] A. Karpińska, K. Borawska-Kalbarczyk (red.), Horyzonty rozwoju edukacji w dialogu i perspektywie, Warszawa: Difin.

Ślusarski J. (2013a), Czy każdy pilot może być instruktorem? Analiza psychologiczna stanowisk pracy pilota i pilota-instruktora śmigłowca wojskowego, Dęblin: WSOSP. 
Ślusarski J. (2013b), Sztuka funkcjonowania w zespole i zarządzania jego zasobami w środowisku, w którym dominuja sytuacje silne, [w:] E. Jaszczyszyn, J. Szady-Borzyszkowska (red.), Edukacja w kreowaniu wspótczesnej rzeczywistości. Możliwości i ograniczenia, t. 2, Siedlce: Uniwersytet Przyrodniczo-Humanistyczny.

Ślusarski J. (2014), Raport końcowy z realizacji projektu badawczego własnego. Sprawozdanie merytoryczne z realizacji projektu badawczego $\mathrm{nr}$ rej. ON 106 020040, nr umowy 0200/B/ T00/2010/40, pt. „Analiza stanowisk pracy pilota, kontrolera i nawigatora jako podstawa doboru treści kształcenia, szkolenia i doskonalenia zawodowego w lotniczej uczelni wojskowej”, Dęblin, WSOSP (opracowanie niepublikowane).

Terelak J. (1988), Wybrane problemy psychologii pracy pilota, Dęblin: Wydawnictwo Wyższej Oficerskiej Szkoły Lotniczej.

Terelak J. (2011), Wprowadzenie do psychologii, wyd. 2 popr. i rozszerz., Białystok: WSAP.

Truszczyński O., Biernacki M. (2010), Skalowanie udziału czynnika ludzkiego w wypadkach lotniczych, „Polski Przegląd Medycyny Lotniczej”.

Zarzadzanie zasobami załogi, https://pl.wikipedia.org/wiki/Zarz\%C4\%85dzanie_zasobami_ za\%C5\%82ogi (dostęp: 10.07.2017).

Znaczenie czynnika ludzkiego w wypadkach lotniczych, http://lotniczapolska.pl/Znaczenie-czynnika-ludzkiego-w-wypadkach-lotniczych,291 (dostęp: 10.07.2017).

\section{SUMMARY}

The character of work of a modern pilot and a flight instructor of military aircrafts, which was shown in the article, was used by the author to focus on the need for increased emphasis on his/her effective training activities as far as soft competences (non-technical) and meta-competences are concerned.

Based on the literature of the subject, the author formulates theoretical assumptions that concern a growing significance of soft competences and meta-competences of workers who are employed in modern organizations. The reasons for this may be connected with growing complexity of tasks that are carried out by the employees in their workplaces and also generating, more and more often, difficult and dangerous situations. Military aviation organizations, defined by the author, require improvement of the employees who work there, in regard to their own and team resources management. The person, who not only in military aviation, has a particular influence on the professional preparation of future aviation staff (military pilots) is a flight instructor. Thus, the work position is the main subject of author's own research that was conducted in a representative aviation staff environment, namely the group of pilots and flight instructors of military aircrafts.

The results of theoretical considerations and analysis, as well as interpretations and the description of data, are conclusions that were formulated at the end of the paper. The conclusions are also practical tips that may be significant in the a process of systematic safety improvement of tasks performed in the air. Each tip, concerning human factor improvement, is of great importance for modern military aviation, since, nowadays, the human factor is responsible for $70-80 \%$ of dangerous situations occurring in aviation (incidents, accidents, catastrophes).

Keywords: flight instructor; character and personality traits; interpersonal relationships; soft competences; non-technical competences; metacompetences; difficult situations; dangerous situations 